\title{
Effects of multiple environmental factors on the elimination of methomyl in aquaculture water
}

\author{
Longxiang Fang ${ }^{1,2,3}$, Chao Song ${ }^{1,2,3}$, Jingwei Zhang ${ }^{1,2,3}$, Shiyun Zhang ${ }^{1,2,3}$, \\ Cong Zhang ${ }^{1,2,3}$, Jiazhang Chen ${ }^{1,2,3}$, Shunlong Meng ${ }^{1,2,3, *}$ \\ ${ }^{1}$ Freshwater Fisheries Research Center, Chinese Academy of Fishery Sciences, 214081 Wuxi, PR China \\ ${ }^{2}$ Laboratory of Quality \& Safety Risk Assessment for Aquatic Products on Environmental Factors (Wuxi), \\ Ministry of Agriculture and Rural Affairs, 214081 Wuxi, PR China \\ ${ }^{3}$ Key Laboratory of Control of Quality and Safety for Aquatic Products, Ministry of Agriculture and Rural Affairs, \\ 100000 Beijing, PR China
}

\begin{abstract}
Methomyl is a highly effective broad-spectrum carbamate pesticide that is widely used in the control of pests and diseases in crops. However, few studies have assessed the degradation of methomyl residues in aquaculture environments. In this study, the effects of $\mathrm{pH}$, temperature, illumination, and aerobic/anaerobic conditions in pond water were analyzed to study the degradation pattern of methomyl. The pesticide residues in all treatments were extracted per solid-phase extraction technique and analyzed using liquid chromatography-mass spectrometry. The results showed that the degradation process of methomyl satisfied the first-order kinetics reaction, and the half-life and percent degradation of methomyl ranged from 6.19-49.33 $\mathrm{d}$ and $21-97 \%$, respectively. Simultaneous variance analysis indicated that all the tested experimental factors had a significant effect on the results, with $\mathrm{pH}$ being the most significant. We conclude that methomyl was used frequently in summer, and that high water temperature and long illumination contribute to the degradation of methomyl. We provide theoretical guidance for the safer use of methomyl in production by further reducing the risk from methomyl residues and further ensuring the safety of products from aquaculture.
\end{abstract}

KEY WORDS: Methomyl $\cdot$ Aquaculture water $\cdot$ Environmental factors $\cdot$ Degradation dynamics

\section{INTRODUCTION}

Methomyl $\left(\mathrm{C}_{5} \mathrm{H}_{10} \mathrm{~N}_{2} \mathrm{O}_{2} \mathrm{~S}\right)$ is a white, crystalline carboximidic acid with a sulfurous odor and a water solubility of $57.9 \mathrm{~g} \mathrm{l}^{-1}$ (Bonatti et al. 1994, Tomašević et al. 2010). It is a carbamate insecticide, and is also an environmental estrogen that is soluble in most organic solvents and has stable chemical properties (Howard 1990, Amer et al. 1996). It can be combined with numerous insecticides for the production of compound insecticides and is widely used in the prevention and control of cotton bollworm, cotton aphid, and phasmids, to name a few (Meng et al. 2013a). The insecticidal toxic mechanism is the inhibition of acetylcholinesterase activity in the insect body (Elas-

${ }^{*}$ Corresponding author: mengsl@ffrc.cn wad \& Badawy 2015), resulting in the excessive excitement and paralysis, and ultimately death, of insect pests. The insecticide acts quickly, can kill both insects and eggs, and is widely used in agricultural and forestry production (Litchfield 1996, Meng et al. 2013a). Globally, methomyl is significant in the prevention and control of pests and is also associated with increased agricultural production and profits (Litchfield 1996).

Only about $1 \%$ of applied pesticide reaches the targeted organisms, while the rest remains in the soil or enters water bodies through direct drainage, surface runoff, leaching, or dry and wet deposition, and this is believed to adversely affect soil and aquatic organisms (Meng et al. 2016). Due to the high solubility of 
methomyl in water and its unregulated discharge in agricultural production, methomyl residues have been detected in water and aquacultural products. These residues may be harming the aquatic ecosystem, and thus pose a threat to water for human use and to fisheries (Strathmann \& Stone 2001, Munshi et al. 2012). Once methomyl enters into the water, it can affect the early growth, sexual differentiation, reproduction, and resource distribution in fish (Meng et al. 2013a). For instance, Meng et al. (2014a) reported that methomyl is highly toxic to tilapia Tilapia mossambica and disrupts endocrine functioning, resulting in abnormal reproductive organs, reproductive functioning and reproductive behavior, thereby causing declines in fertility and damage to biological reproductive functioning. This may lead to population decrease and ultimately species extinction (Gupta et al. 1994, Meng et al. 2013a, Meng et al. 2014b).

The level of pesticide residues in soil and water depends primarily on the pesticide half-life, its water solubility, soil migration, and the amount of pesticide applied. The T0.5 (half-life) of methomyl in soil varies with soil properties and other factors, generally ranging from a few days to $50 \mathrm{~d}$ (Leistra et al. 1984, Scoy et al. 2013). Furthermore, soil properties also have an impact on the migration and adsorption capacity of methomyl in the soil. Typically, humus has a higher adsorption capacity than clay (Cox et al. 1993). Field experimental studies indicated that only $2 \%$ of methomyl remained 1 month after application (Leistra et al. 1984). This suggests that it may not be present as a residue for a long period of time or in a large quantity in the soil in the areas where it is applied. Due to its strong migration and long half-life in soil, it may enter the water via surface water runoff or groundwater (Xu et al. 2016). Studies have found that the half-life of methomyl is greater in water than in soil, and the hydrolyzed half-life in 3 different aqueous solutions ( $\mathrm{pH}$ of 6,7 , and 8 ) were 54,38 , and $20 \mathrm{wk}$, respectively (Yang et al. 2005a, Scoy et al. 2013). This indicates that it may exist in water for a long period of time, causing large quantities of residues in water, which may be harmful to aquacultural products.

Studies have increasingly focused on the techniques for monitoring and measuring methomyl, such as the inspection measurement method (Fernandes et al. 2011, Mirmohseni \& Houjaghan 2013), as well as techniques for removal (Micó et al. 2010, El-Geundi et al. 2012). Further, the toxicological effects and the complex changes in soil and its residues in aquacultural products (Hu et al. 2010, Kim et al. 2013), and the combined effect of its toxicity with other pesti- cides (Meng et al. 2014c, Meng et al. 2016) have also been studied. The present study evaluated the degradation dynamics of methomyl using orthogonal experimental analysis of environmental factors. In this experiment, $\mathrm{pH}$, temperature, covered or open types of experimental glass cylinder, and illumination time were used as impact factors, and the corresponding levels were set based on the breeding cycle and environmental conditions. Liquid chromatography-mass spectrometry (LC-MS) was then used to assess the real-time quantitative degradation. In addition, we explored the relationship between various factors and the elimination rate of methomyl in attempt to find a fast and effective way to reduce the residue of methomyl in water and ensure the safety of aquatic products.

\section{MATERIALS AND METHODS}

\subsection{Instruments and reagents}

The instruments used in this study included an LCMS (Waters), a precision acidity meter (pHS-3C, Shanghai INESA Scientific Instrument), and a solidphase extraction (SPE) system with vacuum manifolds (Shanghai ANPEL Laboratory Technology).

Standard of methomyl (purity $>97 \%$ ) was purchased from Shanghai Focus Biotechnology. The methanol used in this study was chromatographygrade and was purchased from Merck. All the standards used in this study were dissolved in methanol and stored at $-20^{\circ} \mathrm{C}$. $\mathrm{HCl}\left(1\right.$ and $\left.5 \mathrm{~mol} \mathrm{l}^{-1}\right)$ and $\mathrm{NaOH}$ $\left(1\right.$ and $5 \mathrm{~mol}^{-1}$ ) solutions were used to adjust the $\mathrm{pH}$ value of the water used in the experiment.

\subsection{Orthogonal experimental design}

Considering that dissolved oxygen, $\mathrm{pH}$, water temperature and illumination are the main factors affecting the duration of methomyl residues in the environment (Gundersen et al. 1997, Tao \& Tang 2004, Zhao 2009 ,), we selected an open or covered system, $\mathrm{pH}$, temperature and illumination as the influencing factors. The levels of the selected factors were determined based on the pond environmental factors during the experimental period. The orthogonal table was designed using Minitab software, with 2 systems (open or covered) and 3 environmental factors $(\mathrm{pH}$, temperature, illumination), each at 3 levels, creating a total of 18 treatments, i.e. L18 $\left(2 \times 3^{3}\right)$; see Table 1 .

The covered treatments were covered with trans- 
Table 1. L18 $\left(2 \times 3^{3}\right)$ Orthogonal experimental design scheme and the experimental conditions of 18 groups. Each group had 3 replicates

\begin{tabular}{|lcccc|}
\hline $\begin{array}{l}\text { Treat- } \\
\text { ment }\end{array}$ & System & $\mathrm{pH}$ & $\begin{array}{c}\text { Temp. } \\
\left({ }^{\circ} \mathrm{C}\right)\end{array}$ & $\begin{array}{c}\text { Illumination } \\
(\mathrm{h})\end{array}$ \\
\hline 1 & Open & 5 & 20 & 4 \\
2 & Open & 5 & 25 & 12 \\
3 & Open & 5 & 30 & 20 \\
4 & Open & 7.5 & 20 & 4 \\
5 & Open & 7.5 & 25 & 12 \\
6 & Open & 7.5 & 30 & 20 \\
7 & Open & 10 & 20 & 12 \\
8 & Open & 10 & 25 & 20 \\
9 & Open & 10 & 30 & 4 \\
10 & Covered & 5 & 20 & 20 \\
11 & Covered & 5 & 25 & 4 \\
12 & Covered & 5 & 30 & 12 \\
13 & Covered & 7.5 & 20 & 12 \\
14 & Covered & 7.5 & 25 & 20 \\
15 & Covered & 7.5 & 30 & 4 \\
16 & Covered & 10 & 20 & 20 \\
17 & Covered & 10 & 25 & 4 \\
18 & Covered & 10 & 30 & 12 \\
\hline
\end{tabular}

parent plastic wrap to create an anaerobic environment, whereas the open treatments were not covered (aerobic environment). The $\mathrm{pH}$ value of the water was adjusted using $\mathrm{NaOH}$ and $\mathrm{HCl}$ solution, and the $\mathrm{pH}$ of the water was corrected daily. Furthermore, water temperature was controlled by a heating device (50 W heating rod), and air conditioning was used to reduce water temperature fluctuation. Lighting was controlled by an external lighting device $(30 \mathrm{~W}$ fluorescent lamp, cool white light, wavelength 450 peak nm) at around 2500 lux, and the lighting period was controlled using a timing converter. According to the orthogonal design of the software (Minitab 16), there was a total of 18 experimental trials (Table 1), and each treatment was set up in 3 parallel groups, resulting in 54 cylinders. The initial concentration of methomyl in each cylinder was $20 \mathrm{\mu g} \mathrm{l}^{-1}$. The water samples were sampled 7 times within $31 \mathrm{~d}$ (sampled at $0,7,14,18$, $23,27$ and $31 \mathrm{~d})$ to determine the changes in methomyl concentration in the water using LC-MS.

\subsection{Sample analysis}

To ensure a uniform sample, we mixed the experimental water evenly and filled a $20 \mathrm{ml}$ water sample from $10 \mathrm{~cm}$ below the surface in each glass cylinder and placed it in a $50 \mathrm{ml}$ centrifugal tube. Each time
54 water samples were collected. In the covered system, only part of the plastic wrap was opened, thus the dissolved oxygen content was not affected by the rapid stirring and sampling. Then, all the samples were extracted and concentrated using SPE. A Waters HLB extraction column was used and activated with $5 \mathrm{ml}$ of methanol and $5 \mathrm{ml}$ pure water, the water samples were added, and finally, the column was eluted twice with $2 \mathrm{ml}$ methanol and $3 \mathrm{ml}$ methanol. The eluent was collected and shaken well and diluted with methanol once, filtered using a $0.22 \mu \mathrm{m}$ organic phase filter membrane, and transferred into the $1.5 \mathrm{ml}$ Waters sample vial, in preparation for analysis.

The pesticide residues in all samples were analyzed by LC-MS. The chromatographic separation method was as follows. Chromatographic column: ACQUITY UPLC BEH C18 column, $2.1 \times 100 \mathrm{~mm}$,

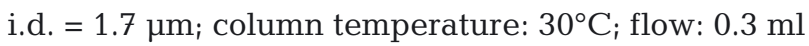
$\min ^{-1}$; injection volume: $5 \mu \mathrm{l}$. The liquid phase was as follows: Solution A: $0.1 \%$ formic acid water, Solution $\mathrm{B}$ : acetonitrile. The gradient conditions are given in Table 2 .

Scanning by mass spectrometry and sample ion collision, we obtained the parent ion (163.136) and 2 daughter ion (88.062 and 106.088) fragments of our target compound; one of them (88.062) was selected as the quantitative ion. The cone voltage was $22 \mathrm{~V}$, and the collision was $14 \mathrm{~V}$ and $12 \mathrm{~V}$, the retention time was $1.24 \mathrm{~min}$. The LC-MS TIC (total ion mass spectrometry) and quantitative ion spectra are shown in Fig. 1.

Mass tuning parameters were as follows. Ion source: positive electrospray ionization $(\mathrm{ESI}+)_{\text {; }}$ detection pattern: multiple reaction monitoring (MRM); capillary voltage: $3.5 \mathrm{kV}$; cone voltage: $30 \mathrm{~V}_{\text {; }}$ source

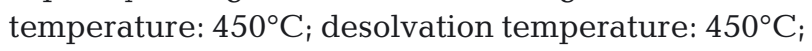
desolvation: $800 \mathrm{l} \mathrm{h}^{-1}$; cone: $50 \mathrm{l} \mathrm{h}^{-1}$.

Considering the degradation of methomyl in water during the experiment, the gradient standard solution was prepared in the range of $1-50 \mu \mathrm{g} \mathrm{l}^{-1}$. A

Table 2. Flow phase and gradient elution conditions of LCMS. A: $0.1 \%$ formic acid water; B: acetonitrile

\begin{tabular}{|lcccc|}
\hline $\begin{array}{c}\text { Time } \\
(\mathrm{min})\end{array}$ & $\begin{array}{c}\text { Flow } \\
\left(\mathrm{ml} \mathrm{min}^{-1}\right)\end{array}$ & $\mathrm{A} \%$ & $\mathrm{~B} \%$ & Curve \\
\hline Initial & 0.3 & 90 & 10 & Initial \\
2.5 & 0.3 & 10 & 90 & 3 \\
3 & 0.3 & 50 & 50 & 6 \\
3.5 & 0.3 & 90 & 10 & 6 \\
5 & 0.3 & 90 & 10 & 6 \\
\hline
\end{tabular}




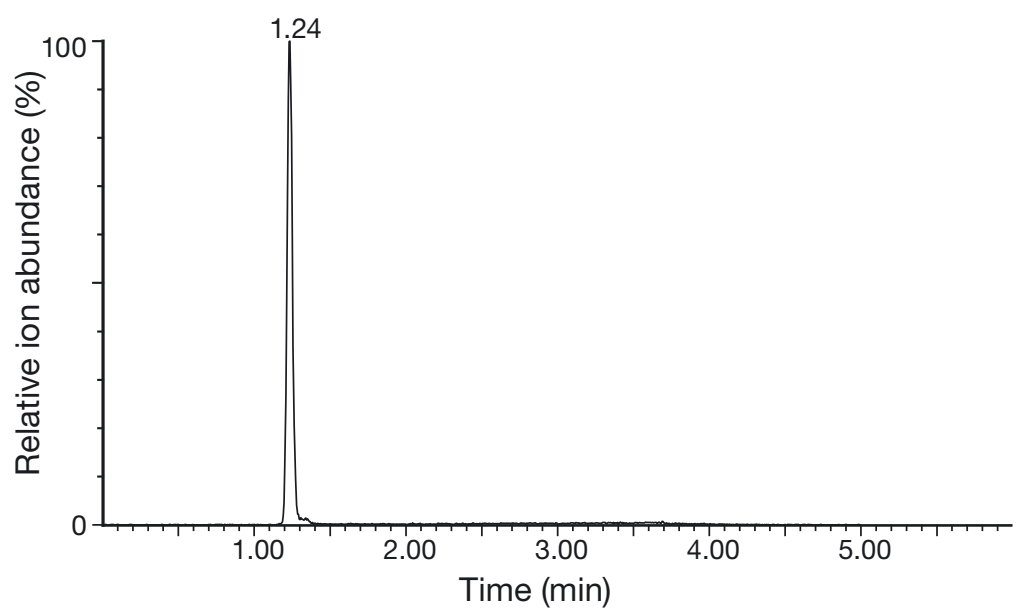

Fig. 1. Liquid chromatography-mass spectograph of methomyl showing the total ion mass spectrum. Concentration of methomyl is $20 \mathrm{\mu g} \mathrm{l}^{-1}$

Statistical analyses were done using SPSS19.0. All data are expressed as mean $\pm \mathrm{SE}(\mathrm{n}=3)$, significance differences were analyzed with a general linear model (ANOVA), the response value was 54 sets of half-life data, and the model was composed of 4 factors, $\mathrm{pH}$, temperature, illumination and open or covered system. The analytical results of half-life data were calculated, and the adjusted SS was used in the test. Data were tested for normality of distribution (Shapiro-Wilk test) and homogeneity of variance (Levene's test) prior to analysis. Data that did not meet assumption of normality and homoscedasticity were transformed $\left(\log _{10}\right)$ and then analyzed by a general linear model ANOVA, and

blank sample was run both before and after the treatment, the standard recovery range was 78.3-115.3\%. The selected daughter ion 88.062, corresponding to the response peak area for ion quantitation, was monitored, and external standards were used for the quantitative calculation of the samples.

\subsection{Statistical analysis}

Based on the mass detection, the first-order reaction kinetics equation was used to calculate the methomyl concentration in the water at various time periods. If a reaction has a single reactant and the value of the exponent is 1 , then it is said to be a firstorder reaction. First-order reactions have many applications, such as in human body drug absorption and elimination and in pollutant degradation (Rehbein et al. 2017). The equation is as follows:

$$
C_{t}=C_{0} \mathrm{e}^{-k t}
$$

where $C_{t}$ represents the concentration of methomyl at time $t, C_{0}$ is the initial concentration of methomyl, $t$ is the duration, and $k$ is the elimination rate constant. T0.5 is calculated by the following equation:

$$
\mathrm{T} 0.5=(\ln 2) k^{-1}
$$

Finally, a range analysis was carried out on the results using the $\mathrm{Rj}$ values to determine the factors influencing the degradation situation of methomyl (K1, K2 and K3 are the averages of the different levels under the same conditions, Rj presents extreme differences in the data under the same treatment condition, namely as maximum K-value minus the minimum K-values). the orthogonal results were analyzed using Minitab at a $95 \%$ confidence level $(\alpha=0.05)$. We expressed the average results of each treatment; the figure data were processed and analyzed using Origin 9.1 (https:// baike.baidu.com/item/origin/503423?fr=aladdin).

\section{RESULTS}

\subsection{Degradation}

Under the experimental conditions, T0.5 and elimination rate of methomyl ranged from 6.19 to $49.33 \mathrm{~d}$ and 0.34 to 0.96 (Fig. 2), respectively. The degradation effect of Treatment $18(\mathrm{pH}=10$, temperature $=$ $30^{\circ} \mathrm{C}$, illumination $=12 \mathrm{~h}$ ) was the most obvious, with T0.5 $=6.19 \mathrm{~d}$ and average elimination rate of 0.96 . Treatment $4\left(\mathrm{pH}=7.5\right.$, temperature $=0^{\circ} \mathrm{C}$, illumination $=4 \mathrm{~h}$ ) showed the slowest degradation rate, with T0.5 = $49.33 \mathrm{~d}$ and average elimination rate of 0.34 . The other treatments showed different degrees of degradation. Most of the experimental groups reached T0.5 within $30 \mathrm{~d}$. It is thus evident that the treatment had a significant effect on the degradation rate of methomyl.

\subsection{Environmental factors}

As shown in Table 3, T0.5 of the Rj values were as follows: within the scope of the level set by the experiment, $\mathrm{pH}$ had the greatest effect on degradation, followed by temperature and illumination, while the open or covered treatments had the smallest effect. ANOVA indicated that the influence of $\mathrm{pH}$ on 


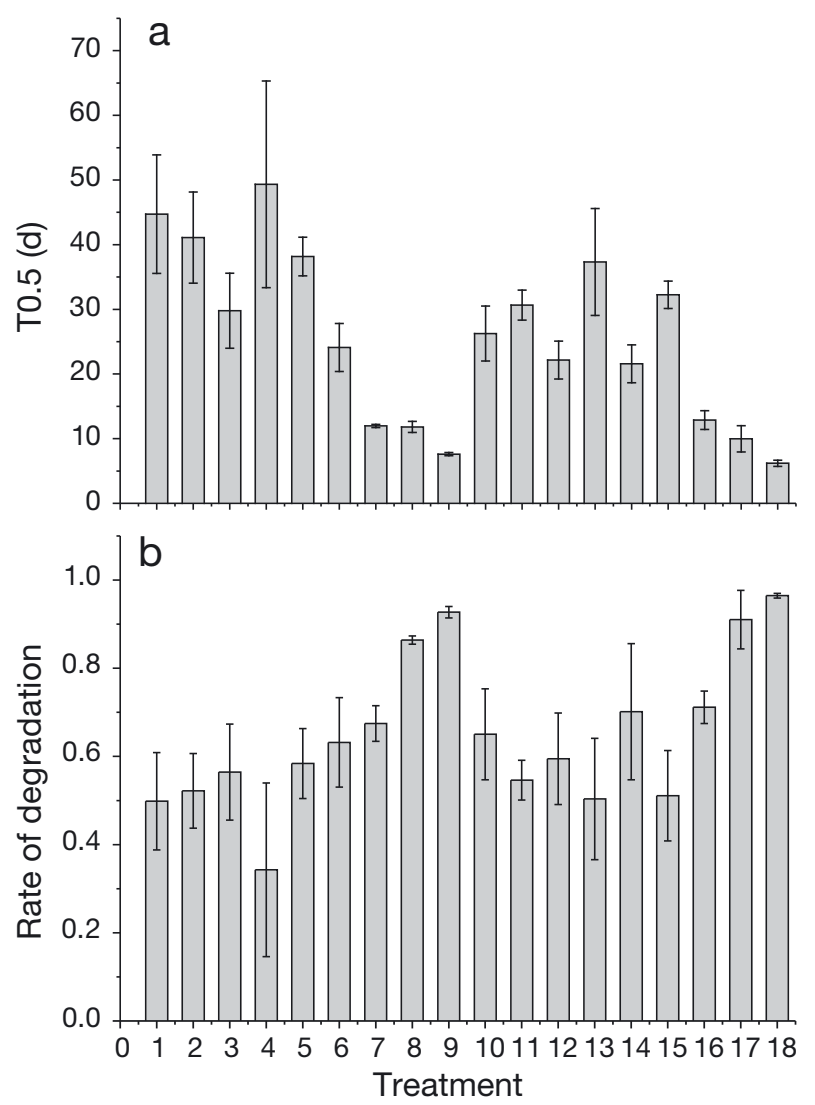

Fig. 2. (a) The half-life (T0.5) and (b) elimination rate of methomyl according to treatment. See Table 1 for treatment details

Table 3. Analysis of the half-life data (d) of the L18 $\left(2 \times 3^{3}\right)$ orthogonal experiment. K1, K2 and K3 are the averages of the different levels under the same conditions, Rj presents extreme differences in the data under the same treatment condition

\begin{tabular}{|lcccc|}
\hline & Open or covered & $\mathrm{pH}$ & Temp. & Illumination \\
\hline K1 & 28.733 & 32.449 & 30.413 & 29.091 \\
K2 & 22.144 & 33.795 & 25.549 & 26.154 \\
K3 & - & 10.071 & 20.353 & 21.070 \\
Rj & 6.589 & 22.378 & 10.060 & 8.021 \\
\hline
\end{tabular}

Table 4. ANOVA of the half-life data of the L18 $\left(2 \times 3^{3}\right)$ orthogonal experiment. SeqSS: continuous SS; adjSS: adjusted SS; adjMS: adjusted MS. Data are significant at $\mathrm{p}<0.05$

\begin{tabular}{|lrrrrrc|}
\hline Factor & df & SeqSS & AdjSS & AdjMS & $F$ & $\mathrm{p}$ \\
\hline Open & 1,10 & 195.36 & 195.36 & 195.36 & 8.24 & 0.017 \\
pH & 2,10 & 2130.76 & 2130.76 & 1065.38 & 44.94 & 0 \\
Temperature & 2,10 & 303.77 & 303.77 & 151.88 & 6.41 & 0.016 \\
Illumination & 2,10 & 197.62 & 197.62 & 98.81 & 4.17 & 0.048 \\
\hline
\end{tabular}

methomyl degradation was highly significant $(\mathrm{p}<$ 0.05). The effects of illumination, temperature and the type of system (open or covered) were also significant, as shown in Table 4.

\section{DISCUSSION}

The T0.5 of methomyl ranged between 6.19 and $49.33 \mathrm{~d}$ and varied with treatment. The factors influencing degradation were in the following order of importance: $\mathrm{pH}>$ temperature $>$ open or covered $>$ illumination (Table 3 ). It is evident that all the 4 environmental factors had significant effects on the rate of degradation (Table 4). The effect of $\mathrm{pH}$ on methomyl degradation was particularly significant and was consistent with range analysis results.

\section{1. $\mathrm{pH}$}

The concentration of acid and alkali can significantly affect the mobility of ions in water systems (Chen et al. 2004). In the present study, $3 \mathrm{pH}$ values $(5,7.5$, and 10$)$ were selected to elucidate the effect of $\mathrm{pH}$ on the degradation of pesticide in fishpond water. Tables $3 \& 4$ show that $\mathrm{pH}$ has a significant influence on the degradation rate of methomyl. The degradation of methomyl in alkaline water was faster (Table 3). This is in agreement with Yang et al. $(2005 a, b)$ who found that the amount of degradation of an organic compound in water is strongly dependent on its existing form (Gundersen et al. 1997). Methomyl is a polar carbamate pesticide that easily hydrolyzes at high $\mathrm{pH}$ values (Elaswad \& Badawy 2015). A hydrolyzed molecule is more easily adsorbed in water due to its higher hydrophobicity compared to an unhydrolyzed molecule.

The effect of $\mathrm{pH}$ as observed in this study can also be explained by the fact that an increase in $\mathrm{pH}$ may enhance the release of organic matter into the solution and consequently result in an increasing rate of pesticide degradation (Tao \& Tang 2004). In addition, a high $\mathrm{pH}$ value, or presence of $\mathrm{Na}^{+}$ and other cationic species, provides more cationexchange sites in the water compared to water with low $\mathrm{pH}$, where $\mathrm{H}^{+}$is the dominant species (Gundersen et al. 1997). This would increase relative availability and increase the degradation rate of methomyl under higher $\mathrm{pH}$ values.

In an aquaculture system, the $\mathrm{pH}$ of water is reduced by the $\mathrm{CO}_{2}$ emitted by aquatic animals such as fish and the acid produced by nitrifica- 
tion reactions, and a low $\mathrm{pH}$ will have a very adverse effect on fish growth (Sipaúbatavares et al. 2016, Kurzbaum et al. 2017). Therefore, pH plays an important role in maintaining the stable operation of fishpond systems. This is consistent with the common practice in fish farms of sprinkling quicklime into a pond at the end of the farming season (Keiblinger et al. 2016), which not only rapidly kills various pathogenic bacteria and promotes the rapid degradation of residual pesticides, but also neutralizes the acidic environment, keeps the pond slightly alkaline, and provides calcium ions for the nutrition of aquatic plants and animals.

\subsection{Temperature}

Three water temperatures $\left(20,25\right.$, and $\left.30^{\circ} \mathrm{C}\right)$ were used to assess how temperature influences the degradation behavior of methomyl (Table 1). Our results showed that the rate of degradation of methomyl in water increased with temperature (Table 3). It is well known that pesticide degradation is a process whereby activation energy is released. The increase in temperature destroys the former steady-state equilibrium, resulting in the degradation equilibrium shifting to the elimination reaction in which a lot of energy is absorbed (Tao \& Tang 2004, Pookmanee et al. 2014). As a result, the amount of methomyl decreased with increasing temperature. Zhao (2009) reported a similar phenomenon whereby the elimination rate was positively correlated with temperature within a certain range of pesticide concentrations. Additionally, the dissolvable organic components in water increase because chemicals are generally easily dissolved into solution under increased temperature (Zhao et al. 2003).

\subsection{Open or covered cylinders}

In this experiment, open (aerobic) and covered (anaerobic) cylinders were used to compare the differences in biodegradation between aerobic and anaerobic systems. When organic pollutants undergo biodegradation, oxygen is one of the important factors that participates in and promotes biodegradation. Our results indicated that the degradation rate in covered cylinders was higher than in the open cylinders, which was unexpected. This is in contrasts with the results of Tai et al. (2018), who found that dissolved oxygen was necessary for the biodegradation of methomyl in aquatic water. One possible ex- planation is that anaerobic bacteria were the dominant species in this system, and thus the biodegradation pathway was more suitable (Chen et al. 2015, Kulkarni \& Kaliwal 2018, Parween et al. 2018). This phenomenon deserves further investigation.

\subsection{Illumination period}

Our results indicated that the illumination period greatly influenced the elimination rate and T0.5. Other studies (Tomašević et al. 2010, Abaamrane et al. 2012, Benhamouda et al. 2017) also found that pesticides were significantly degraded under UV radiation, and no obvious photolysis of methomyl was observed under natural light and in the dark.

\section{CONCLUSIONS}

In the present study, the influence of $\mathrm{pH}$, temperature, illumination, and an open (aerobic) or covered (anearobic) system on the degradation of methomyl was investigated. We discovered that these 4 environmental factors distinctly influenced the degradation of methomyl. When these factors are properly adjusted according to the natural environmental conditions, this can effectively reduce the amount of pesticide residues in water and ensure better water quality. In view of the complexity of factors affecting ponds, as well as the various sources of methomyl, the ecological effects of methomyl residues in ponds still deserve further investigation. After understanding the effects of natural factors on the elimination dynamics of methomyl in aquaculture ponds, studies should be conducted to investigate the effects of various culture dynamics on the elimination of methomyl to better reduce the risk from methomyl residues and to further ensure the safety of aquacultural products.

Acknowledgements. The authors acknowledge the financial support provided by the Central Public-interest Scientific Institution Basal Research Fund, Freshwater Fisheries Research Center, CAFS (No. 2017JBFM07), the special fund for agro-scientific research in the public interest (No. 201503108), and the national quality and safety project of aquatic product of China (GJFP201700903).

\section{LITERATURE CITED}

Abaamrane A, Qourzal S, Billah SM, Assabbane A, Aitichou Y (2012) Modeling experimental design for photo-fenton degradation of methomyl. Open J Appl Sci 2:216-223 
Amer SM, Fahmy MA, Donya SM (1996) Cytogenetic effect of some insecticides in mouse spleen. J Appl Toxicol 16:1-3

Benhamouda K, Belaidi S, Sehili T, Djebbar K (2017) Catalytic photodegradation of rhodamine $\mathrm{B}$ in the presence of natural iron oxide and oxalic acid under artificial and sunlight radiation. Int J Chem React Eng 15:145-152

* Bonatti S, Bolognesi C, Degan P, Abbondandolo A (1994) Genotoxic effects of the carbamate insecticide methomyl. I. In vitro studies with pure compound and the technical formulation 'Lannate 25'. Environ Mol Mutagen 23: 306-311

Chen JP, Pehkonen SO, Lau CC (2004) Phorate and terbufos adsorption onto four tropical soils. Colloids Surf A Physicochem Eng Asp 240:55-61

Chen CS, Wu TW, Wang HL, Wu SH, Tien CJ (2015) The ability of immobilized bacterial consortia and strains from river biofilms to degrade the carbamate pesticide methomyl. Int J Environ Sci Technol 12:2857-2866

* Cox L, Hermosín MC, Cornejo J (1993) Adsorption of methomyl by soils of southern Spain and soil components. Chemosphere 27:837-849

* El-Geundi MS, Nassar MM, Farrag TE, Ahmed MH (2012) Removal of an insecticide (methomyl) from aqueous solutions using natural clay. Alexandria Eng J 51:11-18

Elaswad AF, Badawy ME (2015) Inhibition kinetics of acid and alkaline phosphatases by atrazine and methomyl pesticides. J Environ Sci Health B 50:484-491

Fernandes SC, Vieira IC, Barbosa AMJ, Ferreira VS (2011) Methomyl detection by inhibition of laccase using a carbon ceramic biosensor. Electroanalysis 23:1623-1630

Gundersen JL, MacIntyre WG, Hale RC (1997) pH-dependent sorption of chlorinated guaiacols on estuarine sediments: the effects of humic acids and TOC. Env Sci Technol 31:188-193

Gupta RC, Goad JT, Kadel WL (1994) Energy related metabolic alterations in diaphragm muscle resulting from acute methomyl toxicity. Neurotoxicology 15:321-330

Howard PH (1990) Handbook of environmental fate and exposure data for organic chemicals, Vol 2. Lewis Publishers, Chelsea, MI

$\mathrm{Hu}$ YH, Yang CC, Deng JF, Wu ML (2010) Methomylalphamethrin poisoning presented with cholinergic crisis, cortical blindness, and delayed peripheral neuropathy. Clin Toxicol 48:859-862

Keiblinger KM, Bauer LM, Deltedesco E, Holawe F, Unterfrauner H, Zehetner F, Peticzka R (2016) Quicklime application instantly increases soil aggregate stability. Int Agrophys 30:123-128

Kim E, Moon JK, Choi H, Hong SM, Lee DH, Lee H, Kim JH (2013) Erratum to: exposure and risk assessment of insecticide methomyl for applicator during treatment on apple orchard. J Korean Soc Appl Biol Chem 56:123-123

Kulkarni AG, Kaliwal BB (2018) Bioremediation of methomyl by Escherichia coli. Humana Press, New York, NY

* Kurzbaum E, Raizner Y, Cohen O, Rubinstein G, Bar SO (2017) Lanthanum-modified bentonite: potential for efficient removal of phosphates from fishpond effluents. Environ Sci Pollut Res Int 24:15182-15186

Leistra M, Dekker A, Burg AMMVD (1984) Computed and measured leaching of the insecticide methomyl from greenhouse soils into water courses. Water Air Soil Pollut 23:155-167

Litchfield ML (1996) Environmental health criteria 178: methomyl. Environ Health Criteria 178:132-133

Meng SL, Pao XU, Jian-Hong QU, Song C, Fan LM, Qiu LP,
Chen JZ (2013a) Residue of methomyl in environments and its toxicological effect: a review. Shengtaixue Zazhi 32:2485-2493

Meng SL, Song C, Fan LM, Qiu LP, Chen JZ, Pao XU (2013b) Pollution of environmental endocrine disrupting chemicals (EDCs) in water and its adverse reproductive effect on fish. Jiangsu J Agric Sci 03:463-469

* Meng SL, Chen JZ, Hu GD, Song C, Fan LM, Qiu LP, Xu P (2014a) Effects of chronic exposure of methomyl on the antioxidant system in liver of Nile tilapia (Oreochromis niloticus). Ecotoxicol Environ Saf 101:1-6

*Meng SL, Chen JZ, Xu P, Qu JH, Fan LM, Song C, Qiu LP (2014b) Hepatic antioxidant enzymes SOD and CAT of Nile tilapia (Oreochromis niloticus) in response to pesticide methomyl and recovery pattern. Bull Environ Contam Toxicol 92:388-392

Meng SL, Jian-Hong QU, Song C, Fan LM, Qiu LP, Chen JZ, Pao XU (2014c) Joint toxicity of pesticides methomyl and phoxim to tilapia (Oreochromis niloticus). Nongye Huanjing Kexue Xuebao 02:257-263

Meng SL, Qiu LP, Hu GD, Fan LM and others (2016) Effects of methomyl on steroidogenic gene transcription of the hypothalamic-pituitary-gonad-liver axis in male tilapia. Chemosphere 165:152-162

* Micó MM, Bacardit J, Sans C (2010) Experimental design applied to photo-fenton treatment of highly methomylconcentrated water. Water Sci Technol 62:2066-2066

Mirmohseni A, Houjaghan MR (2013) Measurement of the pesticide methomyl by modified quartz crystal nanobalance with molecularly imprinted polymer. J Environ Sci Health B 48:278-284

Munshi AB, Boardman GD, Lane RB, Flick GJ, Begun S, Cobb J (2012) Impact of endocrine disrupting chemicals (EDCs) on estrone and estradiol content in fish. J Chem Soc Pak 34:396-403

* Parween T, Bhandari P, Sharma R, Jan S, Siddiqui ZH, Patanjali PK (2018) Bioremediation: a sustainable tool to prevent pesticide pollution. Mod Age Env Probl Remediat 30:215-227

*Pookmanee P, Phiwchai I, Yoriya S, Puntharod R, Sangsrichan S, Kittikul J, Phanichphant S (2014) The photocatalytic degradation of methomyl over $\mathrm{TiO}_{2}$ nano powder prepared by the low temperature solvothermal route. Mater Sci Forum 804:209-212

* Rehbein MC, Husmann S, Lechner C, Kunick C, Scholl S (2017) Fast and calibration free determination of first order reaction kinetics in API-synthesis using in-situ ATR-FTIR. Eur J Pharm Biopharm 126:321-326

Scoy ARV, Yue M, Deng X, Tjeerdema RS (2013) Environmental fate and toxicology of methomyl. Springer, New York, NY

* Sipaúbatavares LH, Durigan PA, Berchielli Morais FA, Millan RN (2016) Influence of inlet water on the biotic and abiotic variables in a fish pond. Braz J Biol 77:158-161

Strathmann TJ, Stone AT (2001) Reduction of the carbamate pesticides oxamyl and methomyl by dissolved FeII and CuI. Environ Sci Technol 35:2461-2469

* Tai C, Zhang S, Yin Y, Dai Z and others (2018) Facile photoinduced generation of hydroxyl radical on a nitrocellulose membrane surface and its application in the degradation of organic pollutants. ChemSusChem 11:23-26

Tao QH, Tang HX (2004) Effect of dye compounds on the adsorption of atrazine by natural sediment. Chemosphere 56:31-38

Tomašević A, Kiss E, Petrović S, Mijin D (2010) Study on the 
photocatalytic degradation of insecticide methomyl in water. Desalination 262:228-234

Xu EG, Ho PW, Tse Z, Ho SL, Leung KM (2016) Revealing ecological risks of priority endocrine disrupting chemicals in four marine protected areas in Hong Kong through an integrative approach. Environ Pollut 215:103-112

Yang GP, Zhao YH, Lu XL, Gao XC (2005a) Sorption behavior of o-nitrophenol on marine sediment. Colloids Surf A Physicochem Eng Asp 264:179-186

Editorial responsibility: Alejandro Buschmann, Puerto Montt, Chile
Yang GP, Zhao YH, Lu XL, Gao XC (2005b) Adsorption of methomyl on marine sediments. Colloids Surf A Physicochem Eng Asp 264:179-186

Zhao HX (2009) Study on degradation law of several common pesticides under laboratory conditions. Anhui Nongye Kexue 12:54-56

₹hao XK, Yang GP, Gao XC (2003) Studies on the sorption behaviors of nitrobenzene on marine sediments. Chemosphere 52:917-925

Submitted: August 14, 2018; Accepted: February 12, 2019

Proofs received from author(s): May 6, 2019 